\title{
Urdimento
}

Revista de Estudos em Artes Cênicas

E-ISSN: 2358.6958

\section{Prisons and Activism in the Pandemic: How Survivors of Incarceration Shift What Civic Participation Means}

\author{
Ashley Lucas \\ Alexandra Friedman \\ Efrén Paredes
}

\section{Para citar este artigo:}

LUCAS, Ashley; FRIEDMAN, Alexandra; PAREDES, Efrén. Prisons and Activism in the Pandemic: How Survivors of Incarceration Shift What Civic Participation Means. Urdimento, Florianópolis, v. 3, n. 39, nov./dez. 2020.

DOI: http:/dx.doi.org/10.5965/14145731033920200103 


\title{
Prisons and Activism in the Pandemic: How Survivors of Incarceration Shift What Civic Participation Means
}

\author{
Ashley Lucas ${ }^{1}$ \\ Alexandra Friedman² \\ Efrén Paredes ${ }^{3}$
}

\begin{abstract}
In the midst of the COVID-19 pandemic, currently and formerly incarcerated people in the state of Michigan in the United States are partnering with writers and artists in the free world to make themselves more visible in this moment of crisis. This article looks at three case studies (the MYLIFEMATTERSTOO newsletter, the Living on Loss of Privileges web series, and correspondence programming at the Prison Creative Arts Project) in which people in prison and those who have been recently released are using their creativity and networks of supporters to assert their voices and rights. In doing so, they insist that they are citizens actively participating in free world communities.
\end{abstract}

Keywords: Prison. Activism. Citizenship. Prison newsletter. Web series. Prison arts programming.

${ }^{1}$ Is associate professor of Theatre \& Drama and the Residential College at the University of Michigan. She is the former director of the Prison Creative Arts Project and the co-principal investigator of the Carceral State Project. Her book Prison Theatre and the Global Crisis of Incarceration (Bloomsbury, 2020) examines the ways in which incarcerated people use theatre to counteract the dehumanizing forces of the prison. Lucas is also the author of an ethnographic play about the families of prisoners entitled Doin' Time: Through the Visiting Glass, which she has performed as a one-woman show throughout the U.S. and in Ireland, Brazil, and Canada. She runs the PCAP Brazil Exchange-an exchange program with the Universidade Federal do Estado do Rio de Janeiro and the Universidade do Estado de Santa Catarina-taking students to Rio and Florianópolis each summer to do theatre work inside prisons, hospitals, and favelas. lucasash@umich.edu

2 Is a research assistant for the Carceral State Project at the University of Michigan and is currently the Associate Producer of the web series Living on Loss of Privileges: What We Learned in Prison. She recently graduated from UM with dual master's degrees in Social Work and Music. During her studies, Friedman focused on exploring how music can be used as a tool for community empowerment and growth.

${ }^{3}$ Is a journalist, thought leader, and social justice changemaker who has been incarcerated in Michigan 31 years. He has spoken at events on university campuses around the nation via phone and frequently appears on TV/radio/podcasts discussing criminal justice issues, Black and Latinx Studies, and conflict resolution. His social justice writings are also featured on various websites and blogs. To learn more about Efrén visit http://fb.com/Free.Efren. 
Prisões e ativismo na pandemia: como sobreviventes do encarceramento mudam o que significa participação cívica

\begin{abstract}
Resumo
Em meio à pandemia de COVID-19, pessoas atualmente e anteriormente encarceradas no estado de Michigan, nos Estados Unidos, estão fazendo parceria com escritores e artistas do mundo livre para se tornarem mais visíveis neste momento de crise. Este artigo analisa três estudos de caso (o boletim MYLIFEMATTERSTOO, a série da web Living on LoSS of Privileges e a programação por correspondência no Prison Creative Arts Project) em que pessoas na prisão e aquelas que foram recentemente libertadas estão usando sua criatividade e redes apoiantes para fazerem valer as suas vozes e direitos. Ao fazê-lo, eles insistem que são cidadãos que participam ativamente das comunidades do mundo livre.
\end{abstract}

Palavras-chave: Prisão. Ativismo. Cidadania. Boletim informativo da prisão. Web series. Programação artística da prisão.

Prisiones y activismo en la pandemia: cómo los supervivientes del encarcelamiento cambian lo que significa la participación cívica

\title{
Resumen
}

En medio de la pandemia de COVID-19, las personas encarceladas actualmente y anteriormente en el estado de Michigan en los Estados Unidos se están asociando con escritores y artistas del mundo libre para hacerse más visibles en este momento de crisis. Este artículo analiza tres estudios de caso (el boletín MYLIFEMATTERSTOO, la serie web Living on Loss of Privileges y la programación por correspondencia del Prison Creative Arts Project) en los que las personas encarceladas y las que han sido liberadas recientemente están utilizando su creatividad y sus redes de simpatizantes para hacer valer sus voces y derechos. Al hacerlo, insisten en que son ciudadanos que participan activamente en comunidades del mundo libre.

Palabras clave: Prisión. Activismo. Ciudadanía. Boletín de la prisión. Serie web. Programación de artes carcelarias. 
Nowhere can the devastation of COVID-19 be seen more plainly than inside prisons. The incarcerated cannot socially distance, have inadequate cleaning supplies and personal protective equipment, and receive some of the worst health care to be found in anyone's country. Many who become ill in United States prisons do not wish to be discovered because they will be placed in solitary confinement as a form of quarantine. There these unlucky patients are stripped of their meager possessions-even reading materials. They have nothing to help occupy their anxious minds. They must cope not only with the illness that could kill them but also with limited or nonexistent access to phone calls to loved ones in the free world. Like others throughout the world in this nightmare pandemic, those who die will do so alone without the chance to say goodbye to their families. The COVID survivors in prisons eventually leave quarantine to return to a life of perpetual lockdown. Educational and recreational programs and visitation with loved ones remain indefinitely cancelled.

In the midst of these harrowing times, currently and formerly incarcerated activists are engaging in creative and collaborative forms of resistance and calls for social change. We, the authors of this article, are affiliated with two organizations housed at the University of Michigan--the Prison Creative Arts Project and the Carceral State Project--that enable us to work in meaningful partnership with currently and formerly incarcerated writers, performers, and artists. This chapter focuses on what prison activism on both sides of the walls looks like during the COVID-19 pandemic and how currently and formerly incarcerated activists, and their allies, are responding and adapting to the current crisis.

This chapter highlights three examples of strategic artistic partnerships involving people who have experienced or are experiencing incarceration and allies who have not served time. The first case study examines the MYLIFEMATTERSTOO (MLMT) newsletter which is published in collaboration between incarcerated men at the Gus Harrison Correctional Facility in Adrian, Michigan, and high school students in Nannestad, Norway. MLMT aims to humanize the experience of incarceration by providing a platform to "show and prove that [the lives of those 
incarcerated] have greater significance beyond the sum of their errors." 4 Next we turn to the web series Living on Loss of Privileges: What We Learned in Prison, which features the stories of formerly incarcerated people who share the lessons they have learned in prison that can now help the general public adjust to life during the pandemic. Finally, we discuss how the Prison Creative Arts Project is adapting its programming during the pandemic to maintain community and support those who are incarcerated in Michigan prisons. All three cases demonstrate different artistic modes of activism which serve as platforms for coalition building across prison walls and amplify assertions of belonging from those who have survived or are enduring incarceration. The form of coalitionbuilding activism exemplified in each of these case studies demonstrates not only how currently and formerly incarcerated people are already doing the labor of civic participation but also pushes the boundaries of what citizenship means. It suggests that those who participate in a society, even when they have been written out of the social contract, not only deserve the full rights of citizenship but that they constitute a fundamental part of communities and nations. In the midst of the COVID-19 pandemic, these collaborative activist projects show how people on both sides of prison walls and with disparate life experiences manage to come together, care for one another, and seek a better future for us all. This labor of joining together, particularly in moments of profound crisis, strikes us as fundamentally necessary for citizens in a healthy democracy.

\section{COVID-19 and Prison Activism}

The pandemic has provided a sharp, clarifying lens for the social injustices which have allowed for the carceral state to flourish in all its malignant glory. Awareness of the inhumane conditions within prisons as well as the broader harm caused by the carceral state grows increasingly present in the conscience of the public as the worth and "justice" of the criminal carceral system are sharply called into question. As calls to defund and abolish the police continue to gain force

${ }^{4}$ Quentin Jones. Email to Alexandra Friedman, Ann Arbor, MI, August 10, 2020. 
throughout the nation and the world, now is a critical moment to advocate for dismantling the systems of racism and oppression which have led to the incarceration of 2.3 million people in the United States.

In concert with the activists who have brought revolution to the streets throughout the U.S. in the pandemic summer of 2020, prison activists are working to harness the energy of this crisis for profound social change. The pandemic reveals what we have always known-that prisons are public health disasters; that prisons harm us all, including those who believe they have no relationship to incarceration; that prisons and police function as a theatre of security without actually keeping us safe. People are speaking openly in mainstream venues about disarming the police and even those who are not seasoned activists finally want to know what Angela Davis means when she talks about prison abolition. A wave of progressive prosecutors who want to enable decarceration swept into office in 2019, and many more might be on the horizon.

The potential to shake off many of the chains of institutionalized racism feels present, though its fulfillment will take much labor and a great many miracles. Activists must find a way to do more, to get people out of prison before more of them endure sickness and death, to stop the plague of incarceration from taking further generations from their families and communities. Whatever can be accomplished now will not make right what has already been suffered, will not restore the years and lives that have been taken from so many people-just as the victories of the Civil Rights Movement did not make up for the cruelty, death, and devastation of Jim Crow. Activists cannot let people in prisons slip back into obscurity, where too much of the public can ignore the human rights violations occurring every day inside the walls. To truly usher in an era of change and decarceration, activists on both sides of the walls will be required to think innovatively about their work; work which is made exponentially more difficult by the limitation of rights and citizenship placed on those inside. 
Incarceration and Citizenship: Impacts on Activism and community

Prisons always severely inhibit the civil rights of the people they cage. They also routinely violate human rights and basic health and safety standards. These living conditions and the lifelong trauma they induce have significant impacts on the efforts of currently and formerly incarcerated activists. Imprisonment and the various forms of disenfranchisement that people experience in its aftermath curtail the rights of those who are currently and formerly incarcerated in such a way that distorts citizenship and promotes the misleading popular narrative that these people are no longer part of a community. This subsequently informs the challenges of prison activism. Incarceration mutes the voices of people inside the walls by limiting their ability to share their thoughts with the free world. Many incarcerated people argue it makes them feel diminished and even dehumanized. For an incarcerated person to engage in activities others do in the free world, they must create an elaborate network of communication with people who can help them share their ideas outside of prisons. Imprisoned people must also develop innovative ways to engage with the world to participate in civic activities like free citizens. Though they cannot overcome the physical barriers of their confinement, incarcerated people use their imaginations and collaborate with their free-world allies to devise ways to achieve their goals. While people's bodies can be caged, their minds cannot, unless they surrender them.

Incarcerated people are stripped of many of the rights afforded to free citizens, including the right to vote in all U.S. states except Maine and Vermont. Voter disenfranchisement of formerly incarcerated people functions differently state by state but can result in a lifetime loss of voting rights in lowa, Kentucky, and Virginia. ${ }^{5}$ People in prisons cannot join protests in the streets, and those with criminal records or on probation or parole are more likely to suffer severe longterm legal consequences when they encounter the police. On either side of the

5 “Felony Disenfranchisement Laws (Map)," American Civil Liberties Union website, https://www.aclu.org/issues/voting-rights/voter-restoration/felony-disenfranchisement-laws-map, retrieved 11 August 2020. 
walls, those caught in the net of the carceral state often face attacks online and in social media when they sign their names on political statements, talk to the media, or become a public face for advocacy. Those already punished by the state risk more by engaging in activism than people without ties to prisons do.

However, despite every effort of the carceral state to limit the voice and impact of those who are imprisoned and despite systemic barriers and discrimination that mar life after incarceration, activists both inside the walls of prison and out continue to insist on participating in society and on asserting their belonging in the free world. Activist and journalist Efrén Paredes, who is currently incarcerated in Michigan and a coauthor of this article, writes, "Though incarcerated people may be isolated from the outside world, we do not have to restrict ourselves to the physical limitations imposed on us. We can use our imagination to transcend barriers and connect with the people who are part of our outside community to learn from one another and exchange ideas that are born from different experiences and trajectories in life." Paredes and many other incarcerated people insist on participation in the world outside prisons. Their efforts to engage with communities beyond those trapped in prisons with them lead to a multitude of activist coalitions that cross the literal and figurative walls that divide us. Collectively, the three case studies of artistic collaborations that we discuss in this chapter--and our co-authorship of this article together--present a clear case that those who are formerly and currently incarcerated should enjoy rights as full citizens.

\section{MYLIFEMATTERSTOO}

Due to the oppressive construction of the carceral state, activism from inside prisons is fundamentally constrained and often dangerous. "Prisoners have at their disposal many means to resist the carceral enterprise, ranging from passiveaggressive behavior to the use of the legal system... Many are met with resistance from correctional officers and further sanctions." ${ }^{\circ}$ Because of the restrictions and

6 Jeffrey lan Ross. "Resisting the Carceral State: Prisoner Resistance from the Bottom Up." Social Justice 36, 
risks which plague activism from within prisons, incarcerated activists must find unique ways to both advocate for their rights and participate in society beyond prison. One example of this kind of advocacy and participation is illustrated in the MYLIFEMATTERSTOO: Changing the Narrative of Mass Incarceration newsletter, which was founded by Quentin Jones, who is currently incarcerated at Gus Harrison Correctional Facility in Adrian, Michigan. Jones, who is now forty years old, has been in prison for twenty-one years and is serving a sentence of life without parole.

Figure 1 - Page one of the MYLIFEMATTERSTOO newsletter, Mother's Day edition, published May 2020 describing conditions inside Gus Harrison Correctional facility during the pandemic

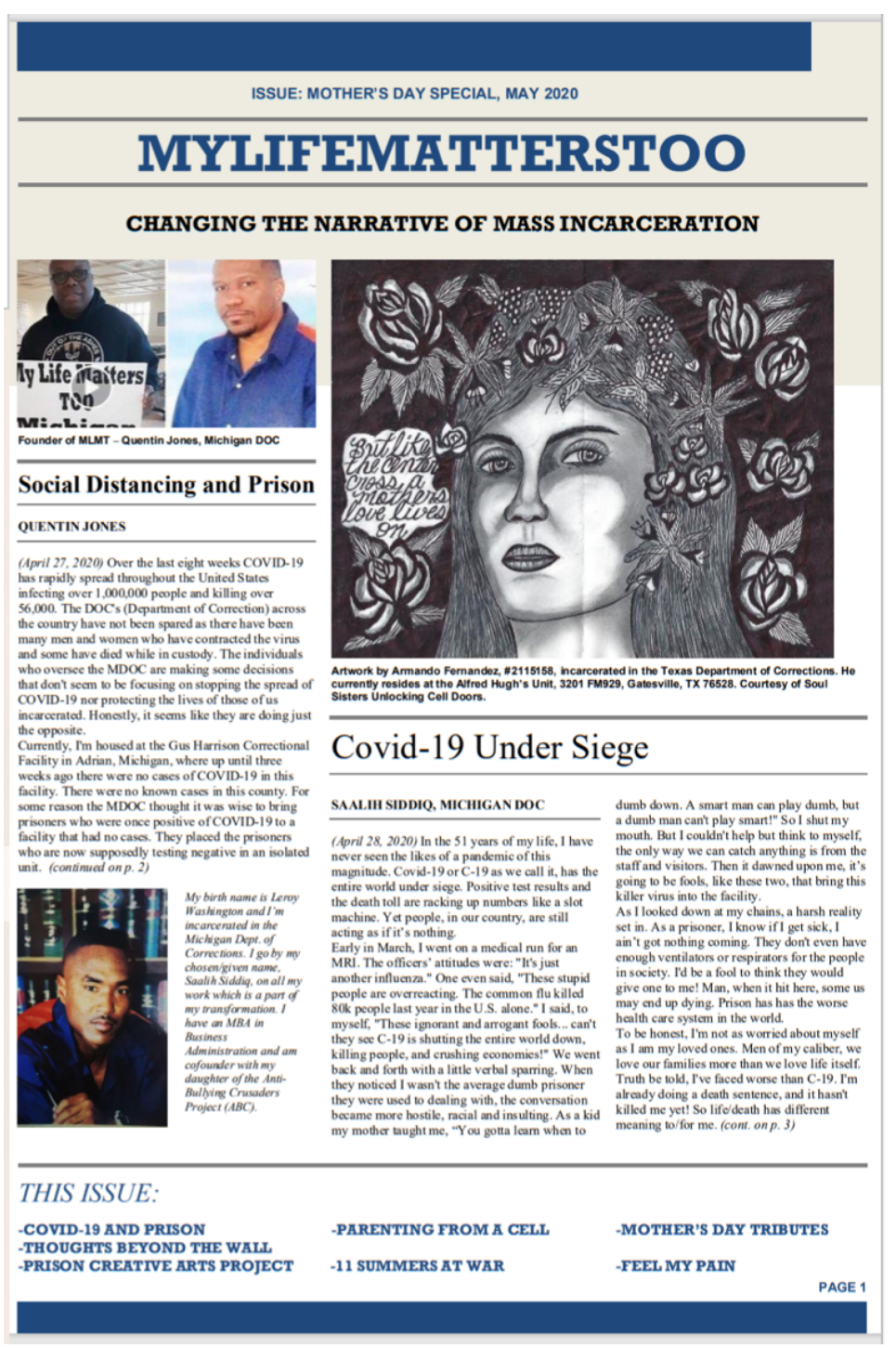


The MYLIFEMATTERTOO (MLMT) newsletter is a collaboration among those incarcerated throughout the United States and students at Nannestad High School in Nannestad, Norway with the mission of "bringing about awareness and change from the inside out through literary and social encounters for a common cause and greater good." With guidance and support from English teacher Marianne Teresa Ruud, students receive letters from incarcerated people across the US and publish their narratives in the quarterly newsletter. This collaboration initially began when Jones wrote a letter to Carlotte Loof, a Dutch activist who corresponds with incarcerated people in the US through the organization Soul Sisters Unlocking Cell Doors. In his letter, Jones expressed an interest in being connected with an educator and working with youth. Loof then connected Jones with Ruud and her students who began to exchange letters with him. This correspondence has evolved into several projects, and $M L M T$ is the latest iteration of this transatlantic partnership.

The newsletter is published in traditional newspaper format and is typically between eight to twelve pages long. Each edition contains personal narratives, poems, and artwork from those who are incarcerated as well as letters and commentary from friends and family members in the free world. The publications are themed and often respond to current events. The May 2020 edition contained several narratives about the harrowing living conditions within US prisons during the pandemic. Currently, the newsletter reaches roughly 500 people and organizations both inside and outside of prisons in the US and Norway. However, in yet another limitation of the rights of those incarcerated, many prisons, including Gus Harrison Correctional Facility, do not allow the newsletter to be distributed inside. This censorship is a typical barrier that activists on either side of the walls encounter when trying to share content within prisons. Because of this restriction, Jones has never seen the final product of the organization which he founded and runs.

$M L M T$ is a unique example of how incarcerated people continue to express their citizenship and advocate for their rights. Jones explained that he has three

\footnotetext{
7 Jones.
} 
main goals for MLMT. "First, I want to change the narrative about men and women who are incarcerated... Second, I wanted to give those of us incarcerated a platform to have our voices heard. Lastly, I hoped to inspire other men and women who are incarcerated to strive to be better human beings and not let incarceration define them." Each of these goals is an impactful expression of citizenship articulated through engagement inside and outside of prison which creates the conditions needed for coalition building.

MLMT serves to strengthen communities both inside and outside of prison. For Ruud, the correspondence she and her students have had over the years has served as an invaluable tool for growth and learning within their school community. She explained, "Working with those on the inside has been one of the greatest educational tools I have ever used and the benefits cannot be measured in any type of material form." She says that not only do her pupils reap tangible educational benefits by learning English through exchanging letters and producing the newsletter, but "it has motivated students to reflect and ponder on their own lives, as the people on the inside have helped them put into words the emotions and burdens they carry."

Additionally, for those inside who contribute to the newsletter, writing offers hope and a sense of belonging. Ricardo Ferrell, a prolific writer who is also serving time in a Michigan prison, explains, "Immediately, after I started sending in pieces for consideration to be published, I began to receive feedback from a lot of people, even as far away as Norway. That experience gave me a different insight, and my perspective was broadened even more about how one's perception of those in prison can become their reality." Similarly, Jones explained that "the newsletter has impacted my experience of being incarcerated by motivating me to pursue my dreams of being a journalist. The continuous spreading of the newsletter has connected me with people in society who can help me further my cause which ultimately has given me hope that better days are coming."10 This active assertion

8 Teresa Ruud, Marianne. "MYLIFEMATTERSTOO.” Email, 2020.

${ }^{9}$ Ricardo Ferrell. Email to Alexandra Friedman, Ann Arbor, MI, August 10, 2020.

10 Jones. 
of belonging in society through ongoing contributions to different communities connected on a global scale is a bold expression of citizenship and serves as just one example of the contributions which those who are incarcerated continue to make, despite the extreme limitations placed on their rights and freedom of speech.

The result of this engagement, the production of the $M L M T$ newsletter, is one model of coalition building activism that provides a tangible platform for those inside to communicate their experiences as well as humanize their voices. Ferrell explained more about his motivation for contributing to the newsletter:

It is not only important but imperative that people in other countries be made aware of Michigan's broken prison system. The [Michigan Department of Corrections'] operations are indicative of an antiquated penological system, in that, its practices when it comes to reforms and rehabilitative measures are lagging far behind other states that have put in place a plethora of programming and classes conducive to an offender's success during his/her incarceration and upon their reintegration back into society... [The newsletter] provides a space for incarcerated individuals to share their stories and allows those inside and outside to express their views, ideas, perspectives, and opinions; freely and openly... It also affords talented artists on the inside an outlet to showcase their creative ingenious. (sic).11

The continued labor of the incarcerated contributors of MLMTto express their humanity adds to ongoing activist efforts to address the negative stereotypes that feed the carceral state.

\section{Living on Loss of Privileges: What We Learned in Prison}

Formerly incarcerated people do not immediately regain citizenship upon their release from prison. This is apparent not only through the denial of their basic rights in civic participation, but it is also socially restricted through malignant stigmatization and "criminal discrimination." 12 As one formerly incarcerated man

${ }^{11}$ Ferrell.

12 Wacquant, Loïc. "Prisoner Reentry as Myth and Ceremony." Dialectical Anthropology 34, no. 4 (2010): 605-20. 
cited in Joshua Price's book Prisons and Social Death explained, "Never think or believe once you've paid your debt to society. There's no such thing. You're not a part of society no more. Never think you're part of society. You're an outcast."13 These restrictions manifest themselves through inadequate funding to the social service infrastructure which assists with reentry as well discriminatory legal and workplace policies. However, despite this marginalization and discrimination, formerly incarcerated people still continue to assert their citizenship through developing and participating in community, and just like activists from inside prisons, formerly incarcerated people find ways to creatively advocate for their rights.

Figure 2 - Patrick Bates, producer and host of Living on Loss of Privileges shooting an episode for the series

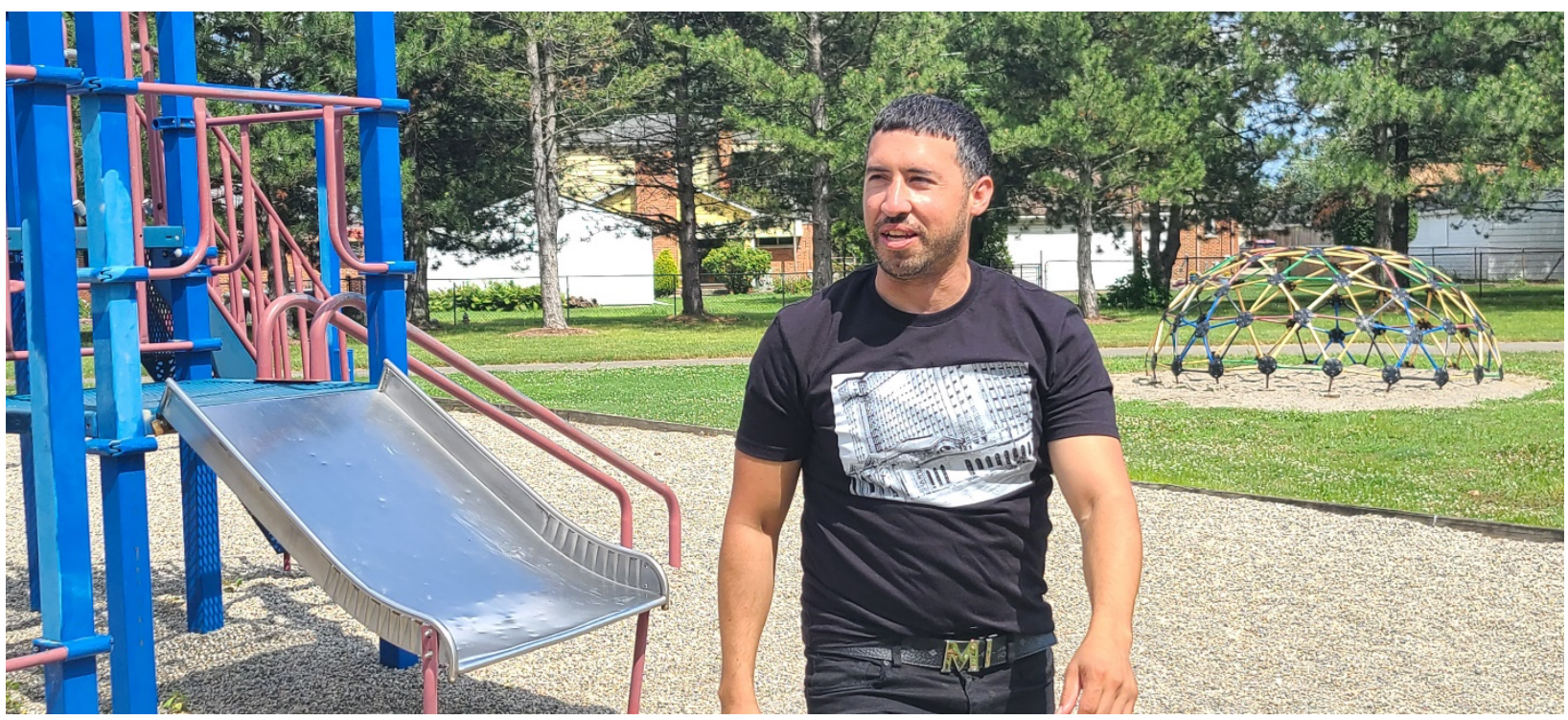

The web series Living on Loss of Privileges: What We Learned in Prison is one example of activism which is imaginatively responsive to both the COVID-19 pandemic as well as to the social stigmatization that is unique to the experiences

Accessed August 28, 2020. http://www.jstor.org/stable/29790988, p. 614.

13 Price, Joshua. Prison and Social Death. Critical Issues in Crime and Society. New Brunswick, NJ: Rutgers $\begin{array}{lllll}\text { University } \quad \text { Press, } 2015 . & \text { Accessed } 2020 . & \text { https://doi- }\end{array}$ org.proxy.lib.umich.edu/10.36019/9780813565590, p. 115. 
of formerly incarcerated people. ${ }^{14}$ This project is a video series initiated by formerly incarcerated artists Patrick Bates and Cozine Welch. Bates had been frustrated by comparisons being drawn on social media between the experience of coronavirus shelter-in-place orders and being in prison; he realized that people who had survived incarceration had useful information and strategies for enduring confinement that others could benefit from hearing while they stay at home. This collection of videos features the stories of formerly incarcerated people who share the lessons they have learned in prison that can now help those in the free world adjust to life during the pandemic.

In Michigan prisons, "loss of privileges," or LOP, is a broad designation for a range of punishments that incarcerated people can suffer as a result of a disciplinary action. Depending on the severity of the offense of which a person is accused, LOP can mean anything from restrictions of one's time in the prison yard to a stay in solitary confinement. The name of the web series, Living on Loss of Privileges, captures the essence of the project as a form of consciousness raising. As producer and host Bates explains, the name contains three different meanings.

[The first is] in reaction to misconduct in prison. What happens as a punishment for any misconduct is that you can be put in the hole for isolation or you can be put on LOP. [The second is the] bigger meaning, the loss of privileges as far as the loss of privileges from society in prison. The third meaning would be the loss of privileges from what people [in the free world] are dealing with right now. Loss of privileges such as not being able to go get your haircut or go to the movies. Those are privileges not rights. ${ }^{15}$

The literal and metaphorical meanings of LOP offer a bridge between those who have experienced isolation in prison and those in the free world who may be struggling to cope with the limitations of the pandemic. As a consciousness raising effort which is foundational to coalition building, LOP enables the narrators of each episode to showcase their thoughtfulness, compassion, wisdom and expertise as

${ }^{14}$ View all episodes of Living on LOP at https://sites.lsa.umich.edu/dcc-project/living-on-lop/.

${ }^{15}$ Bates, Patrick, and Cozine Welch. Interviewed by Ashley Lucas. Personal Interview. Digital. June 18, 2020. https://www.youtube.com/watch?v=-uEZqKs7keU. 
people who have survived incarceration.

Each episode of this series of short videos features a different formerly incarcerated person presenting a strategy for enduring or coping with confinement and elevated stress. Though the narrators of Living on LOP may have different motivations for participating in the project, each clearly is navigating the barriers and prejudice surrounding incarceration. Their engagement in this form of public storytelling is a brave and progressive form of activism. The carceral state is characterized by control, trauma, and violence. The structure and system of reentry, by design, is one of shame and stigmatization. On both sides of the walls, the strength of the carceral state is built on society believing that those who have been to prison not only have nothing to offer the free world, but also actively cause harm. When formerly incarcerated people assert their full belonging and citizenship in society by sharing their knowledge, skills and wisdom, the carceral state begins to lose power. Considering this context, interviewees who participate in Living on LOP are doing foundational prison activist work by confronting a system which has developed its control and durability by perpetuating the narrative that those who have been to prison have little to contribute. Cozine Welch, who is a co-producer and a narrator featured in an episode of Living on $\angle O P$, reflected on the importance of validating the experiences of those who have survived incarceration:

I saw an opportunity to address what is a common thread for folks who are returning home, which is proving their worth. Proving that their story and struggle has worth inherently in it and what value they have therefore gotten out of it... It was a great opportunity to show society that folks who are typically thought to have less or have nothing to contribute to society, through their own experience of forced isolation in prison, are showing you the genius in how they got through it and using that to assist those who are now all of a sudden experiencing loss of privileges. ${ }^{16}$

The narrators of Living on $\angle O P$ have mindfully asserted their wisdom and experiences at the intersection of the collective social anxieties regarding the

${ }^{16}$ Bates, Patrick, and Cozine Welch. Interviewed by Ashley Lucas. Personal Interview. Digital. June 18, 2020. https://www.youtube.com/watch?v=-uEZqKs7keU. 
pandemic and the increased attention being given to criminal justice reform at this time. By contributing their knowledge during a period of social unrest and vulnerability, the narrartors and producers of Living on LOPare not only addressing widespread negative perceptions, discrimination, and stereotypes which currently and formerly incarcerated people face but are also actively contributing to our collective social wellbeing. In this way, Living on LOP serves as a clear expression of citizenship which creates the conditions for coalition-building activism. As people in the free world who may not have previously engaged with criminal justice reform benefit from contributions made by those who are formerly incarcerated, stereotypes can be challenged and replaced with respect and alliance.

\section{The Prison Creative Arts Project's Correspondence Programming}

During the pandemic, the work of activist artists has the ability to keep the struggles of both prison and broader social reform efforts in public view. The murals of George Floyd and other victims of police murder springing up in cities around the world enable us to see and not forget the cost of state violence. Currently, many artists and arts organizations are working both to harness the power of the arts to support prison reform as well as cope with new limitations imposed by the pandemic. One such organization is the Prison Creative Arts Project (PCAP) at the University of Michigan. Founded in 1990, PCAP trains students and community volunteers to facilitate workshops in theatre, visual art, music, creative writing, and photography to incarcerated youth and adults. The facilitators collaborate on an artistic project with the incarcerated members of their workshop, and at the end of the semester they hold a performance, small exhibition, or reading of the work the group has generated. By using the arts as a starting point, PCAP hopes to open up inter-community dialogue amongst groups who do not often communicate with one another. 
Figure 3 - Johnny Trice, serving a life sentence in Michigan, participated in a PCAP photography workshop facilitated by photography lecturer Isaac Wingfield and his students. Trice's artwork appears behind him in the photo. The caption Trice wrote for this self-portrait reads, "When I came to prison, I had blood on my hands, and now I have paint on them."

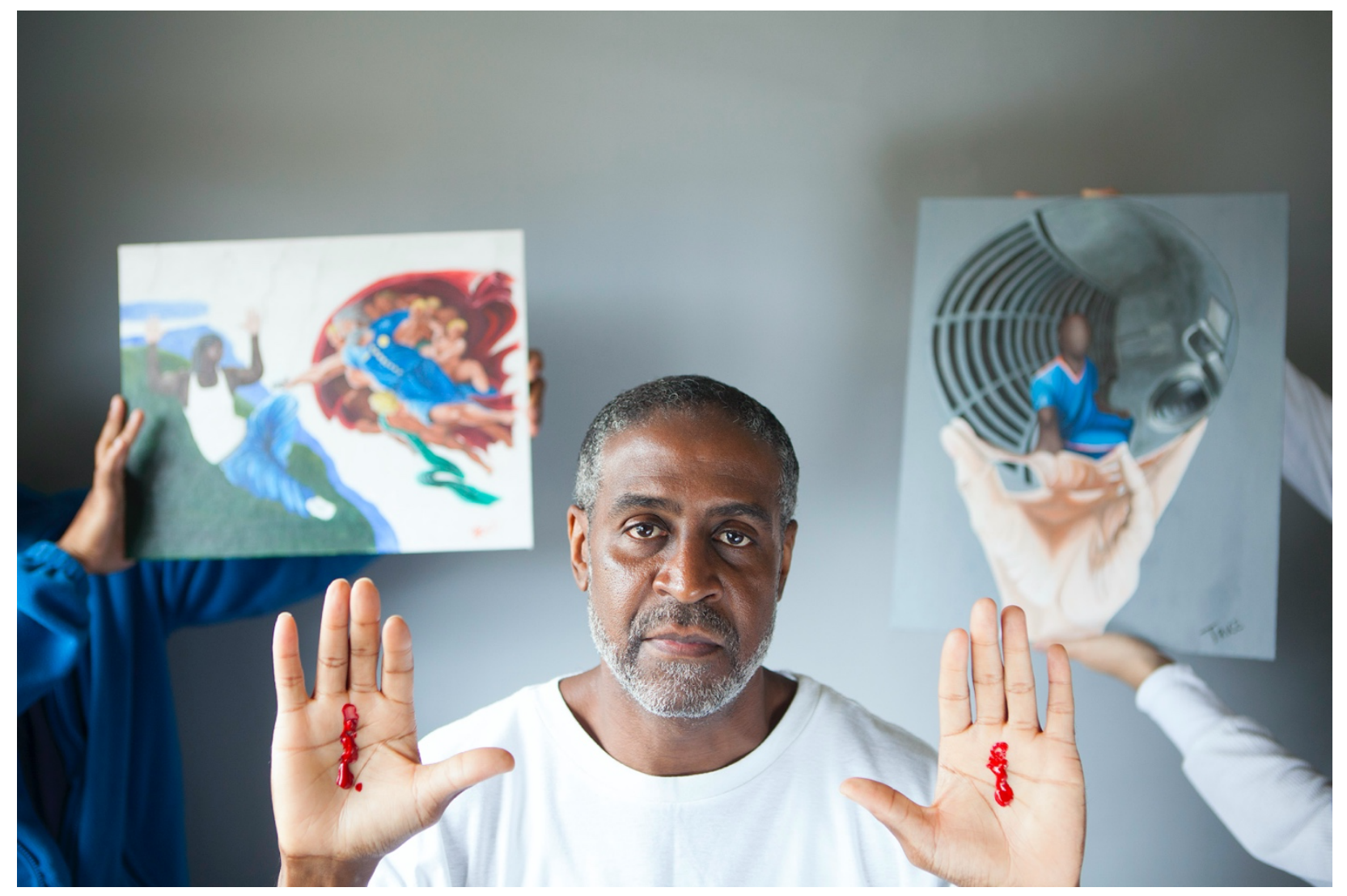

Unlike the Living on LOSS of Privileges web series or the MYLIFEMATTERSTOO newsletter which have always been produced outside of prisons, PCAP has historically done much of its collaborative work inside the walls of carceral facilities. In the pandemic, prisons around the world have forbidden visitors and volunteers to enter, leaving incarcerated people to endure the anxiety, sickness, and death of the pandemic without any physical access to their families or programming. PCAP, like many other prison arts and education programs around the world, had to reformat its programing to be able to continue to provide services to incarcerated people without sending volunteers into prisons. PCAP has revised its curriculum to be delivered in remote, written format where facilitators and incarcerated participants exchange creative works via mail. 
Though nothing can replace the sincerity and solidarity of the connections which form through in-person collaborations week after week, those at PCAP are finding a few unexpected gifts in the necessity of pivoting to remote programming. Historically, PCAP has only been able to offer weekly programming in prisons within about an hour's drive of the University of Michigan's Ann Arbor campus. Now the organization has the ability to reach folks in distant parts of the state with the same frequency. PCAP is hoping to keep the new correspondence programming running at faraway prisons even after in-person workshops can resume. In Fall 2020, for the first time in PCAP's thirty-year history, formerly incarcerated people, including those still on parole, can facilitate weekly workshops inside adult prisons because facilitators are not actually going inside. This opens up deep opportunities for collaboration and helping to build an even stronger network of support for currently and formerly incarcerated participants. PCAP alumni who have moved away from Michigan can also facilitate workshops remotely, and in yet another first, final celebrations of workshops can be shared with a broader public outside the prison. Organizers for correspondence workshops in visual art and creative writing are planning to produce magazines or chapbooks that can be printed and sent back into the prisons and also shared online. Theatre workshop participants are aiming toward collaborative script writing and filmed performances by facilitators which can be shared online for the general public and families of the incarcerated participants to see.

Nothing can replace the level of meaningful interactions that develop by working together in person, but like so many communities that have endured incarceration, the PCAP community has resolved to continue collaborating across prison walls in spite of the unforeseen and overwhelming challenges posed by the pandemic. The shift of PCAP programming, and the determination of those in prison to continue to write, create and share, and the efforts of allies in the free world to find ways to collaborate and promote the work of those inside is yet another example of how incarcerated people continue to assert their belonging outside of prison and express their citizenship through community participation. 


\section{Coalition Building and Social Change}

The three case studies described in this chapter all demonstrate the extraordinary efforts of currently and formerly incarcerated people, with support from allies, to continue to assert their belonging through different forms of coalition building. Such engagement is a fundamental expression of citizenship and is essential for the wellbeing of any community. Despite the extreme and inhumane limitations that are placed on those in prison, and the discrimination which formerly incarcerated people face after returning home, those who have experienced incarceration continue to actively engage in, and contribute to, society. This engagement presents a clear case for why incarcerated individuals should enjoy full rights as citizens.

As Efrén Paredes reminds us, "Everyone has a moral and social responsibility to do what they can to help make a difference in the society in which they live." Citizenship, when functioning at its best, is fundamentally built on the responsibility to engage in community, and social transformation can only occur when communities are fortified through coalition building efforts. Activism is the product of good citizenship. Each project in this chapter exemplifies coalition building as a form of activism which is a clear expression of the moral and social responsibility which define citizenship. For the MYLIFEMATTERSTOO newsletter, those in prison who send in submissions are contributing to the educational and emotional wellbeing of the students at Nannestad High School in Norway. The students in turn create the newsletter which those who are incarcerated would not be able to produce independently because of the extreme confines of prison. The product of this relationship of mutual care and engagement is a platform of activism which focuses on humanizing incarceration and draws attention to the injustices of the carceral state.

Similarly, Living on LOPworks to engage those who may not have any previous knowledge or interest in carceral systems, but may now, during the crisis of the pandemic, benefit from the wisdom of those who have experienced incarceration. 
Through the entry point of examining the challenges of isolation and the limitations of certain privileges which are being experienced globally, the conversation of criminal justice reform can be introduced through the starting point of honoring and acknowledging the skills and wisdom which those who have experienced incarceration have to offer society. Through the LOP narrators' willingness to share their knowledge with a broad community, they are expressing their citizenship in the form of care for others who have less experience with the trauma of confinement.

Finally, for the facilitators and participants of the Prison Creative Arts Project, the mutual learning and growth which occurs over the course of a workshop are direct and invaluable modes of coalition-building activism. Through the shared creation of art, workshop participants from both inside and outside prison become a part of each other's daily lives. As students return from workshops, they share their experiences from PCAP with friends and family which creates more opportunity for dialogue addressing the cruelty and harm of the carceral state. There is a growth of citizenship which expands from each workshop participant as allies in the free world accept, and act on, their civic responsibility to aid those inside with dismantling the carceral state that causes harm to us all.

Despite the tremendous efforts of those who engage in the projects which are described in this chapter, each has its limitations. There are, for example, enormous inequities from prison to prison concerning who is able to participate in programing and limited capacity to accommodate all who wish to participate. This means that those who need it the most (ie. those in greatest isolation and deprivation) often do not have the opportunity to share their writing or stories or to simply come into community with those who acknowledge, honor and appreciate their humanity. Additionally, these efforts of coalition building are small, and often do not reach as far as activists would like. For example, each year since 1995, PCAP has held its Annual Exhibition of Art by Michigan Prisoners. ${ }^{17}$ This exhibition is one of the largest of its kind in the world typically featuring over 500

17 The COVID-19 pandemic forced the first postponement of the exhibition in PCAP's history. At the time of this writing 800 works of art remain in storage waiting for the world to be safe enough for PCAP to hang its 25th annual exhibition. 
pieces of art but does not often receive acknowledgement beyond the local University of Michigan and Ann Arbor communities. Many more resources and time must be invested to elevate this programming to a point where it may have a more direct impact on policy and the broader social conscience. These gaps in service and lack of visibility are among the many challenges which activists associated with these programs continually strive to address.

Despite these challenges, the MYLIFEMATTERSTOO newsletter, Living on LOP and the Prison Creative Arts Project are all doing work which is essential to dismantling the carceral state. Without programs such as these, the carceral state would continue to grow unchecked, with daily human rights violations washed over in prisons across the United States and with those who have experienced incarceration being further marginalized and discriminated against. These efforts may be small, but they are essential. As activists on both sides of the walls continue to engage in whatever ways they can, they are expressing their citizenship, and different allowances of rights, to slowly build a coalition which is essential to effecting change. Despite the cruel and confining limitations of citizenship which are placed on those who are imprisoned, those who are or have experienced incarceration along with their allies continue to assert their belonging and envision a world of truer justice. As Paredes writes, "We have to use our genius to overcome the challenges and barriers that emerge and remain determined to flourish. The ability to transcend difficulty lies within each of us. How we choose to exercise that power is entirely up to us."

\section{Reference}

Bates, Patrick, and Cozine Welch. Interviewed by Ashley Lucas. Personal Interview. Digital. June 18, 2020. https://www.youtube.com/watch?v=-uEZqKs7keU.

"Felony Disenfranchisement Laws (Map)," American Civil Liberties Union website, https://www.aclu.org/issues/voting-rights/voter-restoration/felonydisenfranchisement-laws-map, retrieved 11 August 2020.

Ferrell, Ricardo. Email to Alexandra Friedman, Ann Arbor, MI, August 10, 2020.

Jones, Quentin. Email to Alexandra Friedman, Ann Arbor, MI, August 10, 2020. 
Price, Joshua. Prison and Social Death. Critical Issues in Crime and Society. New Brunswick, NJ: Rutgers University Press, 2015. Accessed August 15, 2020. https://doi-org.proxy.lib.umich.edu/10.36019/9780813565590, p. 115.

Ross, Jeffrey lan. "Resisting the Carceral State: Prisoner Resistance from the Bottom Up." Social Justice 36, no. 3 (117) (2009): 28-45. Accessed August 17, 2020. www.jstor.org/stable/29768547.

Ruud, Marianne Teresa. “MYLIFEMATTERSTOO.” Email, 2020.

Wacquant, Loïc. "Prisoner Reentry as Myth and Ceremony." Dialectical Anthropology 34, no. 4 (2010): 605-20. Accessed August 28, 2020. http://www.jstor.org/stable/29790988, p. 614.

Received: 30/10/2020

Approved: 22/11/2020 